\title{
Implementation of Therapeutic Communication at Dr. Pirngadi Hospital
}

\author{
Syukur Kholil ${ }^{1}$, Lahmuddin Lubis ${ }^{2}$, Syafruddin Ritonga ${ }^{3}$ \\ ${ }^{1,2}$ Lecturer in State Islamic University of North Sumatera (UINSU), Medan, Indonesia \\ ${ }^{3}$ Ph.D Student in State Islamic University of North Sumatera (UINSU), Medan, Indonesia
}

\begin{abstract}
This study aims to study intensively about therapeutic communication at General Regional Hospital of Dr. Pirngadi Medan. This research is a field research with a qualitative approach. In this study researchers used data collection obtained by conducting research directly in the field. The result shows that implementation of Islamic Communication in therapeutic communication carried out by medical personnel at General Regional Hospital of Dr. Pirngadi Medan applies therapeutic communication in Islamic communication, such as greeting when entering a room, greeting each patient before checking and asking about the development of they health. This is a form of communication that must be carried out by every medical personnel. The model of implementation of Islamic communication in therapeutic communication for healing patients at General Regional Hospital of Dr. Pirngadi Medan is Interpersonal Communication which is considered the most effective because of its dialogical nature in the form of conversation.
\end{abstract}

Keywords: therapeutic; communication; Hospital

\section{Introduction}

Good therapeutic communication from a medical professional such as a doctor or a nurse, is able to provide confidence for patients. In this case, the outward impression or appearance of doctors and paramedics as well as hospitality ranging from a smile full of sincerity, neatness to dress, familiar attitude, ways of speaking that give an attractive impression, and personal character with tempered temperament are needed to be the first drug for patients.

In line with what Rogers expressed in Arwani that the core of interpersonal relationships in therapeutic communication is warmth, sincerity, empathic understanding and positive attention. Ideally a doctor and paramedics as communicators are able to show concern, through messages through soft words to patients, so that they can help patients as communicants in the healing process. According to Onong U. Effendy "Interpersonal or interpersonal communication is considered the most effective way in changing one's attitude, opinion or behavior because it is dialogical, in the form of conversations between two or more people who are intertwined by exchanging messages and involving emotions in them".

The hospital should be able to provide a complete service that is a service with a comprehensive therapeutic communication phase starting when the patient first comes to the hospital or orientation phase, then at the work phase, which is to unite the communication process with treatment actions and build a supportive atmosphere for the process of change to the completion phase (termination), namely the assessment of the achievement of goals and separation after completion of treatment through medical consultations and therapists provided by doctors and paramedics in an effort to cure the disease.

Communication is an inseparable part of human life because all our steps are always accompanied by communication. The communication in question is Islamic communication, that is, moral or ethical moral communication. Communication with morality al-karimah means communication that originates from the Al-Quran and Hadith (the Sunna of the Prophet). As A. Muis said, Islamic communication has a difference with non-Islamic. The 
difference is more on the content of the message of communication that must be bound by religious orders, and by itself the element of message content is binding on the communicator element. That is, the communicator must have and uphold the principles of Islamic ethics in delivering messages when talking to patients so that a state of harmony can occur with the patient. In this case doctors, nurses / paramedics.

\section{Review of Literature}

\subsection{Definition of Islamic Communication}

The term communication comes from English. Communication is a process of exchanging information between individuals through a system of symbols, signs, or behavior. Communication is also interpreted as a way to communicate ideas with other parties, both by talking, giving speeches, writing, and doing correspondence.

In Arabic, communication often uses the terms tasawhul and ittishal. For example Prof. Dr. Abdul Karim Bakar when writing about family communication, he gave the title of his book with al-Tawashul al-Usari (Family Communication). The word ittishal is used by Awadh Al-Qarni in his book Hatta la Takuna Kallan (So You Don't Be a Burden for Others). When defining communication, Awad said that communication (ittishal) is to do the best way and use the best means to transfer information, meanings, tastes, and opinions to other parties and influence their opinions and convince them of what we desire to be good with using language and by using others.

When referring to the word basically washala means up. Thus, tawashul can be interpreted as a process carried out by two parties to exchange information so that the message delivered can be understood or reached the two communicating parties. The word Iittishal linguistically emphasizes the aspect of message continuity, it does not have to happen two-way communication. As for the Big Indonesian Dictionary, communication is interpreted as sending and receiving messages or news between two or more people so that the intended message can be understood. In addition, the relationship and contact between two or more people is also referred to as communication.

\subsection{Linkages of Therapeutic Communication with Islamic Communication}

Establishing a good relationship between health workers and patients is absolutely necessary in an effort to expedite the duties of nurses. There are four actions that must be taken in applying the therapeutic relationship between nurses and patients, namely:

a. The action was initiated by the health team

b. Reaction response from patients

c. Interaction

d. Transaction

The relationship between health workers and patients is Islamic in character with the relationship with the concept of God and humanity. Basically the relationship is based or sourced from Al-Quran and Sunnah. The basics of the relationship are as follows:

a. Fellow Muslims or believers are brothers. This is as Allah has explained in the AlQuran Q.S al-Hujurat: 10,

It means: "the real believers are brothers, therefore reconcile between your two brothers and fear Allah, so that you will have mercy" 
b. Do not reproach one another and may not call with bad calls. As Allah has specified in the Al-Quran Q.S Al-Hujurat: 11

It means: "O you who believe, do not make people make fun of other people (because) they may (those who are mocked) be better than those (who make fun of) and women (make fun of) ridicule) other women (because) may be women (who are mocked) better than women (who make fun of) and do not criticize yourself, and do not be ignorant of calling people with bad titles. The worst is the call is a bad (call) after the faith, and those who do not repent then they are the people who do wrong.

c. Not to prejudice one another, find fault, and gossip at others. As Allah has specified in Q.S. Al-Hujurat: 12,

It means: "O you who believe, stay away from most prejudices, in fact some of the prejudices are sins, and do not find fault with other people and do not try to gossip about others. Do any of you eat the flesh of his dead brother? Then surely you feel disgusted with him. And fear Allah. Surely Allah is the recipient of repentance, the most merciful ".

d. Please help with virtue and don't help with sin and hostility. As Allah has specified in Q.S. Al-Maidah: 2,

It means: "O you who believe, do not violate the laws of God, and do not violate the honor of unlawful months, do not (disturb) the animals of had and the animals of Qalaaid, and do not (also) disturb people those who visit Baitullah are looking for the gift and relief from their Lord, and if you have completed the pilgrimage then you may hunt. And do not ever (your) hatred for something common because they prevent you from the Grand Mosque, encourage you to persecute (to them). And please help you in (doing) goodness and piety, and don't help in committing sins and transgressions. And fear Allah, verily Allah is severely tortured.

e. Not insulting each other.

The following are the principles in Islamic therapeutic communication, namely:

a) The health team must be able to understand the basics of relationships and manners in socializing and establishing communication.

b) The health team must always try to implement the basics of the relationship.

c) Always have to muhasabah (introspection) self.

d) Always serve and help patients with all my heart and only hope for Allah's pleasure.

e) The health team must be able to understand and appreciate the level of understanding and religious behavior of patients.

f) The health team must be able to master their own feelings (controlling emotions) and anger. As Allah has specified in the Al-Quran Q.S Ali Imran: 134, It means: (i.e.) those who spend (their wealth), both in the field of time and in narrow space, and forgive (mistakes) people. God loves those who do well.

g) The health team must be consistent and keep their promises.

h) The health team must always be honest, open and responsible. This is also the principle in Islamic communication.

\section{Research Method}


This research is a field research with a qualitative approach. In this study researchers used data collection obtained by conducting research directly in the field. This study aims to study intensively about Islamic communication in therapeutic communication practices in Medan city government hospitals.

The location of the study focused on General Regional Hospital of Dr. Pirngadi Medan as General Regional Hospital. The reason in choosing these hospital is because they are the most representative in analyzing therapeutic communication patterns between doctors, nurses and patients. In addition this hospital is a hospital that receives the most people in the lower middle class category.

\section{Discussion}

Based on interviews conducted with Dr. Fitri, it can be seen that the doctor has implemented Therapeutic Communication at General Regional Hospital of Dr. Pirngadi Medan. Therapeutic communication aims to enable a doctor to get to know her patients and easily in the treatment process. This can be seen from the conversation of Dr. Fitri ${ }^{1}$ at the time of entering the room, namely greeting (good morning, good afternoon, and good night), because it has become a habit and has become a hospital procedure.

The purpose of this is to make the patient aware that the doctor will be examining). Furthermore, what is done by the doctor is to introduce self-identity for patients who are just entering first. However, if the patient has been in a few days and has already been examined, the doctor will immediately inquire about the patient's news so that the patient feels cared for by asking about the patient's latest condition every time he has an examination. Usually the time needed by Dr. Fitri examined the patient for about five minutes, and even then included asking about the development of his health, complaints and then checked her health.

In carrying out the examination there must be a patient who is difficult when taking medication. What is done by the doctor so that the patient is willing to be examined and take medication is an approach with the patient and tells the patient well and motivation to recover quickly by taking regular medication. Usually the duty of a doctor in treating a patient is certainly an obstacle, that is, the patient is difficult to examine. The solution taken by the doctor is by asking the patient's family to cooperate in handling the examination. But if there are patients who are difficult to comfort patients to calm down during a medical examination or taking medication.

After all, the duty of a doctor is a noble duty. Therefore a doctor must be prepared when there are patients who really need it at any time. In addition, in the medical code of ethics, doctors should not refuse if there are patients who need treatment. Therefore, doctors must be patient when he must leave his time with family, because the duty of a doctor is to serve sincerely and sincerely. He must be patient when facing patients who are difficult, both in the examination or when they want to take medicine. He must work lovingly. But there are also things that must be confirmed if there are people who are having difficulty taking medicine, depending on the type of patient. In addition, the obstacles faced are other than patients who have difficulty taking medicine. To deal with patients as above the doctor tries

\footnotetext{
${ }^{1}$ Fitri, Dokter, Interview in General Regional Hospital of Dr. Pirngadi Medan at 010.05 WIB.
} 
to communicate with the patient first and if it is difficult the doctor will ask the family member of the patient who is looking after the patient.

The second interview was conducted with Dr. Nova. ${ }^{2}$ Based on interviews conducted by researchers with Dr. Nova, it can be seen that Dr. Nova has applied the principles of therapeutic communication in serving her patients. As for the principles of therapeutic communication that he applied were like saying good morning, good afternoon, or good night, depending on the time when he examined the patient. Furthermore, Dr. Nova also introduced herself to patients if they had only been hospitalized one day before examining their patients. This is intended to establish closer relations between doctors and patients. When giving treatment to patients, Dr. Nova also be patient, because this has become part of a doctor's job, namely to serve with sincerity and patience. If you experience problems facing patients who have difficulty taking medication and incomplete examination tools and patients who ask to go home, then he will give advice patiently, and involve the patient's family to participate in advising patients and maximizing existing examination equipment so that patients continue to get treatment with well. Also important is Dr. Nova also always asked about the development of the patient's health and motivated the patient to recover immediately from the pain he was suffering from and always tried to provide sincere and loving service.

Quality of care is an important aspect of a hospital. The quality of services provided by nurses in a hospital is closely related to the satisfaction felt by patients as hospital customers. "Quality in health service is fully meeting the needs of those who the service most, at the lowest cost to the organization, within limits and directives set by higher authorities and purchasers."3

Nursing services in the effort of health services in hospitals are determinants of the image and quality of hospitals. In nursing, the aim of service quality is to ensure that the services or products produced by nurses are in accordance with the standards / wishes of patients. ${ }^{4}$ If the service received or felt is as expected, the service quality is perceived as good. If the quality of service received exceeds consumer expectations, the quality of the service it receives is considered to be an ideal quality, whereas if the quality of service received is lower than expected, then the quality of service is considered poor. The services provided by nurses greatly affect the success or failure of a service because it involves the wants and needs and demands of patients as consumers. ${ }^{5}$

Quality of service can be divided into 3 basic expectations, there are:

a. The criteria / standards applied must be appropriate

b. Information collected to determine whether service standards can be met.

c. Learning and correction is needed if there are standards that cannot be carried out.

\footnotetext{
${ }^{2}$ Nova, Dokter, Interview in General Regional Hospital of Dr. Pirngadi Medan at 11.18 WIB.

${ }^{3}$ John Ovretveit, Health Service Quality: An Introduction to quality methods for Health Service (Cambridge : Cataloguing in Publication Data,1992), p. 2.

4 M. Nurs Nursalam, Manajemen Keperawatan: Aplikasi dalam Praktik Keperawatan Profesional (Jakarta: Salemba Medika, 2002), p 297.

5 Indra, and Gunarsih," Pengaruh Kualitas Pelayanan Terhadap Kepuasan Nasabah Kredit Perorangan Dan Kelompok: Studi Kasus Pada PD BPR Bank Pasar Kabupaten Karanganyar”. Jurnal Manajemen. Vol 2 tahun 2002, p. 67.
} 
Skills and abilities are defined as a level of individual achievement of efforts to complete their work properly and efficiently. Physical skills are obtained from learning by using skills at work. The development of these skills can be done in the form of training.

A person's behavior is greatly influenced by how and what is obtained from the family environment. The family plays a role and functions as the formation of a value system that will be followed by each family member. In this case the family teaches how to achieve life and what we should do to face life. Experience (years of work) is usually associated with time to start work where work experience also determines one's performance. The longer the work period, the skills will be better because it has adjusted to his work.

Nurses who directly or indirectly provide nursing care to individual patients, families and the community. The nurse acts as a comforter, protector, advocate communicator, and rehabilitator. Nurses provide counseling to clients (individuals) who are under their responsibility. Proper counseling, nursing care will get better results.

This role has nurses with structural positions in hospitals. Nurses must monitor and guarantee the quality of nursing care and organize and control the nursing service system. Participating in the development of a body of knowledge of nursing, nurses must have the ability to conduct research in their fields. Ability to research, nurses can identify nursing problems that the results can improve the quality of nursing care and nursing education. ${ }^{6}$

The nurse's relationship with the patient is as follows:

a. Nurses in providing services, nurses respect the dignity and human dignity, uniqueness of the client and are not affected by consideration, nationality, ethnicity, skin color, age, sex, political and religious affiliations, and social position.

b. Nurses in providing nurse services always maintain an environment that respects the cultural values, customs, and religious survival of the client.

c. The nurse's primary responsibility is to those who need nursing care.

d. Nurses must keep everything that is known in connection with the duties entrusted to him unless required by the authorities in accordance with applicable legal provisions.

The quality of nurse care is an important aspect that is seen as part of the hospital such as being willing to listen to patient complaints, getting to know the patient well, being a good listener and being able to solve or remember patient problems that require effective communication between nurses and patients. Conducting therapeutic communication helps patients and nurses in contact, not only in interaction but also the healing process of patients not only physically but also mentally. Therapeutic communication is professional communication that aims at the goal of healing the patient. Interpersonal communication between nurses and patients due to mutual need and prioritize mutual understanding that is planned consciously using certain expressions or cues and aims to cure the patient.

Therefore, in assessing the quality of nurse services by providing therapeutic communication, the services provided by nurses will be considered good for patients. The Quality of Nurse Services becomes an important assessment for hospitals, the services provided to patients become a mandatory concern so that comfort and satisfaction are met. Nurses who provide services need to establish good relations with patients in order to become aware of the problems faced.

\footnotetext{
${ }^{6}$ Ardia Putra, "Hubungan Komunikasi Terapeutik Perawat Dengan Kepuasan Pasien di Ruang Rawat Inap Rumah Sakit Umum Daerah dr. Zainoel Abidin”, Jurnal Ilmu Keperawatan, vol. I no. 1, p. 53
} 
The nurse and patient relationship needs ordinary communication, but therapeutic communication. This therapeutic communication is not only to establish a good relationship with patients, but also helps patients reduce anxiety or mental problems that prevent healing. If using therapeutic communication, the quality of service provided by nurses is good and right. However, if no therapeutic communication is carried out, the quality of nurse services has not been met.

Based on interviews conducted with Mrs. Nursahara, ${ }^{7}$ it can be seen that the nurse has implemented Therapeutic Communication at General Regional Hospital of Dr. Pirngadi Medan. The existence of Therapeutic communication that aims so that a nurse can get to know his patients and easily in the process of patient care. This can be seen from the conversation of Mrs. Nursahara when entering the patient's room always saying hello if I know Muslim patients so I say assalammualaikum and if non-Muslim patients I say greetings or good morning or evening. In addition, he also introduced himself before examining patients. He also always advises patients well if patients are lazy to eat or take medicine.

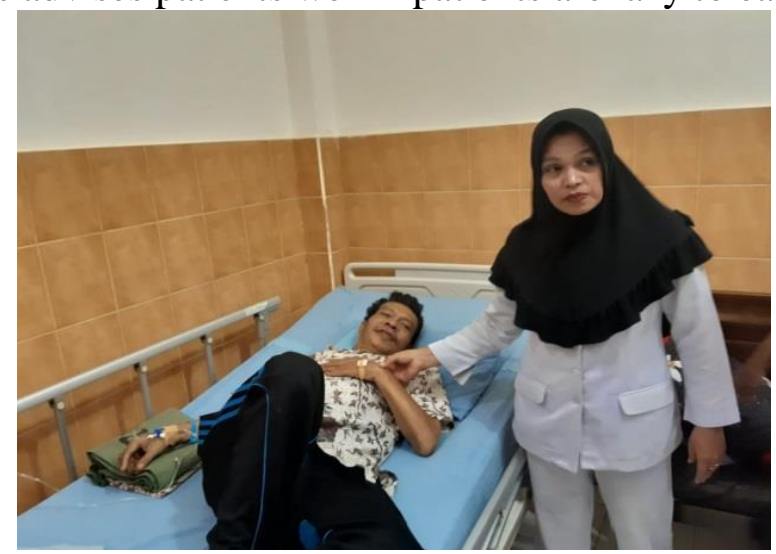

Figure 3. The nurse checks the patient's health

The task of a nurse is also not easy, that is when finding a patient who has difficulty speaking due to illness and patients who have hearing loss. In addition, he also sought a solution from his constraints as a nurse, namely trying to communicate with patients first and if it was difficult to handle patients, he would ask the family members of patients who take care of these patients. Therefore the main thing done by a nurse is to be patient. He also always questions the development of the patient's health when he wants to treat, and hear the complaints of his patients after that check his health. In addition, when he found his patient's health was getting worse, then what he did was trying to heal and motivate patients to stay motivated to heal. Keep in mind that the duty of a nurse is to serve sincerely and honestly.

The second interview was conducted with Mrs. Tinta Malam Sebayang. ${ }^{8}$ In general, she has also applied the principles of therapeutic communication when serving his patients. In more detail it can be seen from the results of the following interview. Based on interviews conducted with Mrs. Nursahara, it can be seen that the nurse has implemented Therapeutic Communication at General Regional Hospital of Dr. Pirngadi Medan. The existence of Therapeutic communication that aims so that a nurse can get to know her patients and easily in the process of patient care.

\footnotetext{
${ }^{7}$ Wawancara with Mrs. Nursahara at General Regional Hospital of Dr. Pirngadi Medan

${ }^{8}$ Tinta Malam Sebayang, Nurse, interview in General Regional Hospital of Dr. Pirngadi Medan at 11.30 WIB.
} 
The most important thing done by Mrs. Tinta Malam Sebayang when she met her patients was saying goodbye, good morning, good afternoon, good night. After that, he also introduced himself to patients first to be more familiar with patients. What he did when he found patients who are lazy to eat and take medicine is to advise patients patiently to want to eat and take the medicine.

Surely in every job there are obstacles or problems in dealing with patients. However, in overcoming the obstacles he did, namely trying to communicate with patients first and if it is difficult I will ask the family members of patients who take care of these patients. He also always asked about the development of health, and listened to every patient complaint when he examined the patient. In addition she tried to cure patients and motivate him to keep the spirit to recover. Because the attitude of a doctor and nurse in dealing with patients must serve sincerely. As a nurse, they should always be ready to assist doctors in providing services to patients.

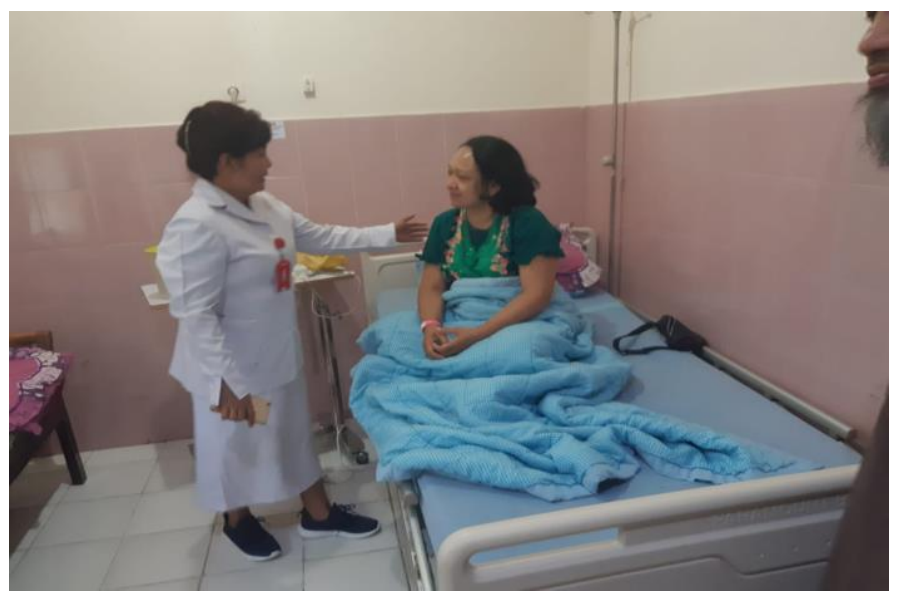

Figure 4. The nurse motivates the patient

\section{Conclusion}

Implementation of Islamic Communication in therapeutic communication carried out by medical personnel at General Regional Hospital of Dr. Pirngadi Medan applies therapeutic communication in Islamic communication, such as greeting when entering a room, greeting each patient before checking and asking about the development of they health. This is a form of communication that must be carried out by every medical personnel.

The problem faced by medical personnel in the implementation of Islamic communication in therapeutic communication for healing patients at General Regional Hospital of Dr. Pirngadi Medan is the impossibility of medical practitioners to always say Assalamu'alaikum, this is because not all patients in General Regional Hospital are Muslim. So it is not possible for these Islamic customs to be applied during the therapeutic communication process at General Regional Hospital of Dr. Pirngadi Medan. In addition, the problems experienced by medical personnel are interacting with patients who experience hearing loss so that medical personnel find it difficult to apply therapeutic communication. In implementing therapeutic communication, medical personnel also experience problems such 
as patients who are seriously ill so that patients have difficulty communicating with medical personnel so that therapeutic communication does not take place effectively.

The model of implementation of Islamic communication in therapeutic communication for healing patients at General Regional Hospital of Dr. Pirngadi Medan is Interpersonal Communication which is considered the most effective because of its dialogical nature in the form of conversation.

\section{References}

Abdurrahman bin Nashir bin Abdullah al-Sa'di. Tafsir al-Karim al-Rahm fi Tafsir Kalam alMannan (Mu'assasah al-Risalah, 1420 H-2000 M).

Abu al-Qasim al-Husain bin Muhammad. (1412). Al-Mufradat fi Gharib al-Quran. Dimasyq: Dar al-Qalam.

Ali bin Muhammad bin Ali al-Zain al-Syarif Al-Jurjani, (1403-1983). Al-Ta'rifat. Beirut: Dar al-Kutub al-'Ilmiyyah.

Ardia Putra, "Hubungan Komunikasi Terapeutik Perawat Dengan Kepuasan Pasien di Ruang Rawat Inap Rumah Sakit Umum Daerah dr. Zainoel Abidin", Jurnal Ilmu Keperawatan, vol. I no. 1.

Amir, Mafri. (1999). Etika Komunikasi Massa Dalam Pandangan Islam. Jakarta: Logos.

Armilatussholihah, (2011). "Pola Komunikasi Perawat dan Pasien Rawat Inap dalam Pelayanan Medis di Rumah Sakit Universitas Islam Negeri (UIN) Syarif Hidayatullah-Jakarta", Fakultas Ilmu Dakwah dan Ilmu Komunikasi Universitas Islam Negeri Syarif Hidayatullah Jakrta.

Borman, Ernest G. (1989). Retorika Suatu Pendekatan Terpadu. Jakarta: Erlangga.

Cangara,Haffied. (1998). Pengantar Ilmu Komunikasi. Jakarta: Raja Grafindo Persada.

Daly, Mark L. Knapp \& John Augustine. (2002). Handbook of Interpersonal Communication. New York: Cambridge University.

Damaiyanti, M. (2008). Komunikasi Terapeutik Dalam Praktik Keperawatan. Bandung: Rafika Aditama.

Deddy Mulyana, (2005). Ilmu Komunikasi Suatu Pengantar. Bandung: PT Remaja Rosdakarya.

Devito, Joseph A. (1991). Human Communication, The Basic Course. New York: Harper Collins Publisher.

Departemen Kesehatan Republik Indonesia tahun 2002.

Diamond, Jared. (2013). Guns, Germs, and Steel (Bedil, Kuman, dan Baja, Rangkuman Riwayat Umat Manusia. Jakarta: KPG.

Dinas Kesehatan Kota Medan, Provinsi Sumatera Utara.

Drajat. (2008). Komunikasi Islam dan Tantangan Modernitas. Bandung: Citapustaka.

Effendi, Onong uchjana. (2000). Dinamika Komunikasi. Bandung: Remaja Rosdakarya.

Effendy, Onong Uchjana. (2000). Ilmu Komunikasi Teori dan Filsafat Komunikasi Bandung, PT. Cipta Aditya Bakti,.

Fairus Ali Abdad, (2012). "Tingkat Pengetahuan Perawat Tentang Komunikasi Terapeutik di Unit Rawat Inap Umum Rumah Sakit Dr. H. Marzoeki Mahdi Bogor”, Fakultas Ilmu Keperawatan Universitas Indonesia, Jakarta.

Fitriarti, Etik Anjar. (2017). Komunikasi Terapeutik Dalam Konseling (Studi Deskriptif Kualitatif Tahapan Komunikasi Terapeutik dalam Pemulihan Trauma Korban 
Kekerasan Terhadap Istri di Rifka Annisa Women's Crisis Center Yogyakarta. Skripsi Fakultas Ilmu Sosial dan Humaniora Universitas Islam Negeri Sunan Kalijaga Yogyakarta.

Foss, Stephen W. Littlejohn, and Karen A. (2005). Theories of Human Communication, eighth edition. Thomson Wadsworth: Belmont, CA.

Gonnick, Larry. (2007). Kartun (non) Komunikasi. Jakarta: KPG.

Halah Abdul 'Al al-Jamal, (2008). Fann al-Tawashul fi al-Islam.

Hamid Mowlana. (1998). Global Communication as Cultural Ecology. Canada: International Comparative Research Group stratetegic and Analysis Canadian Heritage.

Hannad bin Sari. (1975). Kitab Zuhud. No. Hadits 1227, Hadits Maqthu, Ibnu al-Qayyim, Ighatsat al-Lahfan:1/79. Beirut: Dar al-Ma'rifah.

Hartono, Farida Kusumawati, and Yudi. (2010). Buku Ajar Keperawatan Jiwa. Jakarta:Salemba Medika.

Hefni, Harjani. (2015). Komunikasi Islam. Jakarta: Kencana Prenada Media Group.

Hefni, Wahyu Ilaihi and Harjani. (2015). Pengantar Sejarah Dakwah. Jakarta: Kencana.

Huberman, Matthew B. Miles and A. Michael. (1992). Analisis Data Kualitatif. Terj. Tjetjep Rohendi Rohidi. Jakarta: UI Press.

Hussain. (1990). Dua Puluh Lima Soal Jawab, Mengenai Komunikasi Islam. Pengarah, Pusat Pengembangan dan Pendidikan Lanjutan, Universiti Pertanian Malaysia. Serdang Selangor, Darul Ehsan.

Ibnu Mandzur, Lisan al-'Arab. Beirut: Dar Shadir, 1412-1992. juz 13.

Ibnu al-Qayyim. Kitab al-Wabil al-Shoyyib min al-Kalim al-Thayyib. Beirut: Dar al-Kitab alArabi, 1985-1405.

Imam Muslim, Shahih Muslim (Beirut: Dar Ihya al-Turats al-'Arabi, t.t), juz 1. Hadist no. 1.

Informasi Kegiatan Pelayanan Medik RSUP H. Adam Malik, 1993.

Interview with dr. Fitri at Regional public hospital of Dr. Pirngadi Medan

Interview with dr. Nova at Regional public hospital of Dr. Pirngadi Medan

Interview with Mrs. Nur Sahara at Regional public hospital of Dr. Pirngadi Medan

Interview with Mrs. Tinta Malam Sebayang at Sahara at Regional public hospital of Dr. Pirngadi Medan

Interview with dr. Alwinsyah at General Hospital of Haji Medan

Interview with dr. Dwi Ayu at General Hospital of Haji Medan

Interview with dr. Kautsar at General Hospital of Haji Medan

Interview with Mrs. Yuliana at Provincial General Hospital of H. Adam malik Medan

Interview with Mr. Tomblok at Provincial General Hospital of H. Adam malik Medan

Interview with Mr. Heriadi at Provincial General Hospital of H. Adam Malik

Interview with Mr. Sukri Sembiring at Provincial General Hospital of H. Adam Malik

Islamil Haqqi bin Mustafa al-Istanbul al-Hanafi al-Khalwati. Ruh al-Bayan. Beirut: Dar al-

Fikr, t.t. Indra, \& Gunarsih," Pengaruh Kualitas Pelayanan Terhadap Kepuasan Nasabah Kredit Perorangan Dan Kelompok: Studi Kasus Pada PD BPR Bank Pasar Kabupaten Karanganyar”. Jurnal Manajemen. Vol 2 tahun 2002.

Jasfar, F. Manajemen Jasa : Pendekatan Terpadu. Bogor: Ghalia Indonesia, 2005.

Kamus Besar Bahasa Indonesia (Jakarta: 2007).

Kamus Besar Bahasa Indonesia. Pusat Bahasa Departemen Pendidikan Nasional Republik Indonesia, 2008. 
Kariyoso. Pengantar Komunikasi Bagi Siswa Keperawatan. Jakarta: Buku Kedokteran EGC, 2000.

Kholil, Syukur. Komunikasi Islam. Bandung: Cita Pustaka, 2007.

Koentjaraningrat. Pengantar Ilmu Antropologi. Jakarta: Aksara Baru, 1986.

Kozier. Fundamentals of Nursing; Concepts, Process and Practice, seventh edition. United States: Pearson Prentice Hall, 2004.

Kumpulan makalah, Pembahasan dan Resolusi pada Congress of Muslim Librarians and Information Specialists di University Utara Malaysia, Kedah Malaysia, 20-22 Oktober 1986.

Moch. Khafidz Fuad Raya. "Terapi Komunikasi Terapeutik Islam Untuk Menanggulangi Gangguan Psikologis Anak Korban Bullying" Proceedings Annual Conference For Muslim Scholars Kopertais IV Surabaya.

Muchyiddin, Ase S. Pendekatan Sumber-sumber Informasi Dalam Proses Komunikasi dan Diseminasi Informasi. Bandung: PT Remaja Rosdakarya, 1998.

Muhammad Abdullah Adzhim al-Zarqani. Manahil al- 'Irfan. Beirut: Dar al- Fikr, 1996.

Mulyana, Deddy. Ilmu Komunikasi: Suatu Pengantar. Bandung: Remaja Rosdakarya, 2013.

Muis, Andi Abdul. Komunikasi Islam. Bandung: Remaja Rosdakarya, 2001.

Mustafa, Ibrahim dkk. Al-Mu'jam Al-Wasith. Kairo: Dar al-Da'wah.

Nasir. Komunikasi dalam Keperawatan: Teori dan Aplikasi. Jakarta: Salemba Medika, 2009.

Nina Siti Salmaniah Siregar, "Komunikasi Terapeutik Dokter dan Paramedis Terhadap Kepuasaan Pasien dalam Pelayanan Kesehatan Pada Rumah Sakit Bernuansa Islami di Kota Medan", 2016.

Nursalam, M. Manajemen Keperawatan: Aplikasi dalam Praktik Keperawatan Profesional. Jakarta: Salemba Medika, 2002.

Ovretveit, John. Health Service Quality: An Indroduction to quality methods for Health Service. Cambridge: Cataloguing in Publication Data, 1992.

Potter, P.A \& Perry, A.G. Fundamental of Nursing Concepts, Process and Practice, third edition. St. Louis: Mosby Year Book, 1993.

Purwanto, Hery. Komunikasi Untuk Perawat. Jakarta: EGC,1994.

Prihatiningsih, Fitria Ayuningtyas dan Witanti. Komunikasi Terapeutik pada Lansia di Graha Werdha AUSSI Kusuma Lestari, Depok”, dalam Jurnal Media Tor, Vol. 10 no. 2.

Profil RSUP H. Adam Malik Medan, 1998

Profil RSUP H. Adam Malik Medan, 1997

Rakhmat, Jalaluddin. Islam Aktual. Bandung: Mizan, 1996.

Rakhmat, Jalaluddin. Psikologi Komunikasi, Edisi Revisi. Bandung : PT Remaja Rosda Karya, 2005.

Ririn Tri Ratnasari, Aksa Mastuti H. Manajemen Pemasaran Jasa. Jakarta, Ghalia Indonesia, 2011.

Ritonga, Muhamad Husni. Eksistensi Ilmu Komunikasi Islam. Bandung: Citapustaka, 2008.

Saefullah, Ujang. Kapita Selekta Komunikasi Pendekatan Budaya dan Agama. Bandung, Simbiosa Rekatama Media, 2007.

Setianti, Yanti. Komunikasi Terapeutik antara Perawat dan Pasien, Makalah Ilmiah Fakultas Ilmu Komunikasi. Universitas Padjajaran Jatinagor, 2007.

Sakdiah, Halimatus. Jurnal Ilmu Dakwah Vol. 15 No. 30, Juli-Desember 2016.

Siregar, Ashadi. Etika Komunikasi. Yogyakarta: Penerbit Pustaka, 2008.

Sugiyono. Metode Penelitian Kuantitatif, Kualitatif dan R\&D. Bandung: Alfabeta, 2010. 
Sundeen, dan Stuart. Keperawatan Jiwa Edisi 3. Jakarta: EGC, 1998.

Surachmad, Winarno. Pengantar penelitian ilmiah : dasar, metode dan teknik. Bandung: Tarsito, 1989.

Suryani. Komunikasi Terapeutik; Teori dan Praktik. Jakarta: EGC, 2005.

Taufik, M. Tata. Etika Komunikasi Islam. Bandung: Pustaka Setia, 2012.

Taqiyyuddin Abu al-Abbas Ahmad bin Abdul Halim Ibnu Taimiyah al-Harrani, Majmu' alFatawa. Al-Madinah al-Munawwarah: Mujamma' al-Malik Fahd Li Thiba'at alMushaf al-Syarif, 1416-1995.

The New American Webster Dictionary. New York: A Signet Book.

Tim Redaksi Pustaka Yustisia, Undang-undang Kesehatan dan Rumah Sakit, Yogyakarta: Pustaka Yustisia, 2010.

Trisnantoro, Laksono. Aspek Strategis Manajemen Rumah Sakit Antara Misi Sosial dan Tekanan Pasar. Yogyakarta, Andi, 2005.

Ulber Silalahi. Metode Penelitian Sosial. Bandung; PT. Refika Aditama, 2009.

Webster's New Collegiate Dictionary edisi tahun 1977. Ebook.

Wijaya, et al. Komunikasi Terapeutik. Bandung: Akademi Kesehatan Gigi Depkes RI, 2000.

Wursanto. Etika Komunikasi Kantor. Yogyakarta: Kanisius, 1991.

Zainuddin Abu Abdillah Muhamm bin Abi Bakar bin Abdul Qadir al-Hanafi al-Razi. Muhktar al-Shihah. Beirut: Al-Maktabah al-'Ashriyyah, 1420-1999.

Zamroni, Mohammad. Filsafat Komunikasi:Pengantar Ontologis, Epistimologis, Aksiologis. Yogyakarta: Graha Ilmu, 2009. 